\title{
Spatial Reflections of Social Change: The Change of Urban Pattern in the Ottoman Era
}

\author{
By Fulya Üstün Demirkaya*
}

Cities established thousands of years ago reach our day as products of continuous development in the historical process. While cities are reshaped under new governments every time in the vicious cycle of establishment, expansion, destruction and reestablishment, this process is accompanied by changes in physical appearance. In this sense, there is a rich context in terms of social and structural-spatial change in the establishment of an Ottoman urban texture with its genuine characteristics, meeting of a city with the Ottoman factor, and the qualities of the changes in the previously owned heritage. Undeniably, the gaining of this shape by the Ottoman city that is described as genuine, was affected by the Byzantium and Seljuk urban culture as well as the Arabic-Islamic urban culture. Ottoman cities were formed and organized over this historical background. This study aims to explain which changes/transformations took place in the Anatolian cities with more than three millennia of settlement tradition due to practices known as "the Ottoman tradition" by presenting the spatial structure of the AnatolianOttoman city and elements forming the urban texture. Thus, it is important to reveal the acquired heritage first. The reshaping of cities that were shaped based on Byzantium and/or Seljuk cultures in the light of political, economic, demographic and other social changes with the Ottoman conquest, especially continuities, are discussed in the context of transformation. However, considering the long time period when the empire was in power and its broad area of land that is distributed in three continents; the study covers the process that started in the era of conquest where cities met Ottoman elements for the first time, and reaching the Tanzimat reformation that represents something other than the traditional Ottoman city concept, where new reforms were applied.

"As this wave from memories flows in, the city soaks it up like a sponge and expands.

The city, however, does not tell its past, but contains it like the lines of a hand, written in the corners of the streets, the gratings of the windows, the banisters of the steps... every segment marked in turn with scratches, indentations, scrolls." ${ }^{1}$

Cities founded thousands of years ago that still exist in the present day are a result of their continuous development throughout history. In this manner, cities are not only institutive, economic or political objects, but are

\footnotetext{
*Assistant Professor, Karadeniz Technical University, Turkey.

1. I. Calvino, Invisible Cities, trans. W. Weaver (Orlando: Harcourt Brace, 1974), 1011. 
also architectural phenomena ${ }^{2}$ throughout the historical development process.

The real characterization of a physical space can only be obtained over time. City spaces, which undergo changes and transformations, have been restructured throughout history by wars and migrations. As cities recycle between the processes of founding, expanding, destruction, and re-founding in the hands of new occupants, this process included physical changes each time.

After the emergence of cities and noticeability of settlement segmentation, the structuring of cities is determined by the shape of external relations of cities and the qualities of their social structure. ${ }^{3}$ Life started within the city by and within the walls, which were considered safe as cities were founded, expanded beyond the walls over time, and mostly expanded to areas where the trading took place. Following this long transformation process of city structures, physical structures and institutional models were modeled after a combination of forts, villages, and bazaars.

This physical changes occurring in the city during the founding process is connected with social events and relationships. Each society is in a process of change in every moment, and each factor that triggers social changes plays an important role in each of the processes; they affect each other and can redirect the transformation of the city. In this continuity in which each aspect articulated the others, images that made it impossible to separate one city from another in terms of the definition of an ideal city were developed. A city that could be identified with a single description can be defined through these new images. In short, a colorful environment occurs in cities with the addition of each person by the changing beliefs of each era and society, culture, and religion. As stated by Braudel, ${ }^{4}$ cities are actually engines that are constantly in motion. However, the issue that should be emphasized here is that, although change takes place in a short time period, its effects on the physical structure or the form of the city stay much longer. ${ }^{5}$

There is a delay in social change and the successive change in the urban form in terms of changes in structure. ${ }^{6}$ Sometimes, the new function may also be met in the existing physical structure or change in urban form may take place much later than the functional change. This is a continuous process. A city's physical structure or urban form in a section of time is a

2. N. Özaslan, Konstantinopol'da Bir Osmanlı Kentinin Kuruluşu: Eyüp, [Birth of an Ottoman town in Constantinople: Eyüp], Osmanlı Mimarlı̆̆ının 7 Yüzyılı "Uluslarüstü Bir Miras" (Istanbul: Yapı Endüstri Merkezi Publications, 1999), 238-243.

3. I. Tekeli, Anadolu'da Yerleşme Sistemi ve Yerleşme Tarihleri [Anatolian Settlement System and Settlement Dates] (Istanbul: TVYY, 2011), 36.

4. F. Braudel, Uygarlıkların Grameri [Grammar of Civilizations], trans. M. A. Kılıçbay (Istanbul: Imge Publications, 2006).

5. S. Aktüre, 19. Yüzyıl Sonunda Anadolu Kenti Mekansal Yapı Çözümlemesi [Analysis of Spatial Structures at the End of the 19th-century Anatolian Cities] (Ankara: ODTÜ Mimarlık Fakültesi Basım İşliği, 1981).

6. K. Dziewonski, "Typological Problems in Urban Geography," Geographia Polonica, 2(1964): 139-144. 
result of functional differentiations that take place in a broad time period and in different incidences. Due to this characteristic, it is inevitable to discuss a wide-spectrum analysis of urban form in terms of the relationships of urban functions-spatial structure-urban form. ${ }^{7}$

While a settlement's history might go back thousands of years, Anatolia, which changed rulers many times, has a city culture that is a symbolical reflection of each occupant's institutional system. In this manner, changes in the physical texture developed due to political, social, economic, and cultural dynamics, The Ottoman empire represents a different era of physical changes in terms of those obtained in heritage and the evolution of this unique heritage.

In this manner, the studied subject can be defined as research into how applications that are named "Ottoman Traditions" played a role in the spatial changes of Anatolian Cities. The Tanzimat Era in the frame of the westernization/modernization idea joined to the Ottoman politics where new reforms were applied and has great differences from the "traditional" was excluded from the study. The shaping of the "Anatolian-Ottoman" city following the meeting of Anatolia with the Ottomans and the changes that take place as a natural process connected to this, are discussed in terms of especially continuities and transformation by establishing a relationship between social structure and causality.

The method used in the study to present the spatial structure of the Anatolian-Ottoman city is as following: as the Ottoman city has been shaped and organized ${ }^{8}$ over the Seljuk -Byzantium and Arab-Islam urban cultures, it is first needed to describe how Anatolian cities were shaped under the Byzantium and Seljuk rules and what the elements of the urban texture are. As for almost any period, the most important resource in determining the physical structure of cities is the presence of periodic structures. Therefore, first of all, a literature review was conducted to review the studies on Byzantine and Seljuk urban history and urban life, and the general framework defined by the elements of urban texture, the positions of these elements, and their interrelations was monitored visually by diagrams. With the same method, the functional areas of the Ottoman city were determined, and the position of these areas that are joined onto the pre-Ottoman urban texture and their effects on the change/development in the physical texture were investigated. The general framework established regarding the Ottoman urban texture was also demonstrated visually.

\section{City Concept: Acquired Heritage}

Different dimensions such as institutional, demographical, socioeconomic, social and cultural are present in a city's concept. Cities with only institutional and demographic dimensions can be settlements that reach

7. Aktüre, 19. Yüzyll Sonunda Anadolu Kenti Mekansal Yapı Çözümlemesi, 1981).

8. T. Baykara, "Osmanlı Devleti Şehirli Bir Devlet Midir?" ["Is the Ottoman State a Urban State?"], Osmanl, vol. V (Ankara:Yeni Türkiye Publication, 1999), 528-535. 
a certain population; however, this is not the proper scale for the conception of a city.

In this manner, founding a city, which was described by Plato ${ }^{10}$ as "the greatest merit of mankind" is a process. City foundation is the behavior integrity that is formed by the settlement of cultural accumulation and the behavior regarding historical heritage, changing purposes and altered needs over time and the integrity of the parts when pieced together. ${ }^{11}$ In short, people and societies determine the form of cities based on their beliefs, cultures and religions. ${ }^{12}$ This format might show deviation in different cultures for different reasons (religious-ethnical structure, administrativepolitical terms, geographical-climate terms, demographical development).

The Ottoman city is one of the best examples of this integrity that defines multiple dynamics; while representing the basis of the Byzantine and Seljuk city culture, Arab-Islam cities that were influenced by the conquest of Aleppo, Damascus, Baghdad, and Cairo, are an important factor in this formation (Figure 1). The Byzantine city, which form the first stage of these factors that can be identified as inherited factors, has a developed market economy, an organized ${ }^{13}$ economic life with the development of modest houses, churches, monasteries and small shops under the protection of military outposts while having governors as bishops. ${ }^{14}$

9. Considering that there are interactions of multiple reasons for emergence of cities; Lampard questions the origin of cities in a framework of interrelations determined by variables of population accumulation, technological capacity, organization and environment. According to Lampard, the determining factor in this framework is transition from collecting food to producing food. According to Sjoberg, three conditions are needed for emergence of cities. These are suitable ecological infrastructure, technology, social organization and a developed structure of hegemony. Childe, by mentioning differences of cities, explains the differences in reasons that paved the way to cities and the forms of emergence of cities as the geographical structures, demographic structures and cultures of societies. R. Aslanoğlu, Kent, Kimlik, Küreselleşme [Urban, Identity, Globalization] (Bursa: Asa Publications, 1998), 23.

10. Platon; Devlet [The Republic] (İstanbul: Remzi Publication, 1992)

11. T. Cansever, Islamda Şehir ve Mimari [City and Architecture in Islam] (Istanbul: Timaş Publications, 2012), 115.

12. T. Cansever, Osmanlı Şehri [Ottoman City] (Istanbul: Timaş Publications, 2012), 17.

13. Aktüre, 19. Yüzyıl Sonunda Anadolu Kenti Mekansal Yapı Çözümlemesi, 1981, 7.

14. K. Rheidt, City or Village? Housing and Settlement in Middle and Late Byzantine Anatolia, Tarihten Günümüze Anadolu'da Konut ve Mimarlı [Housing and Settlement in Anatolia A Historical Perspective] (Istanbul: TVY, 1996), 221-233. 


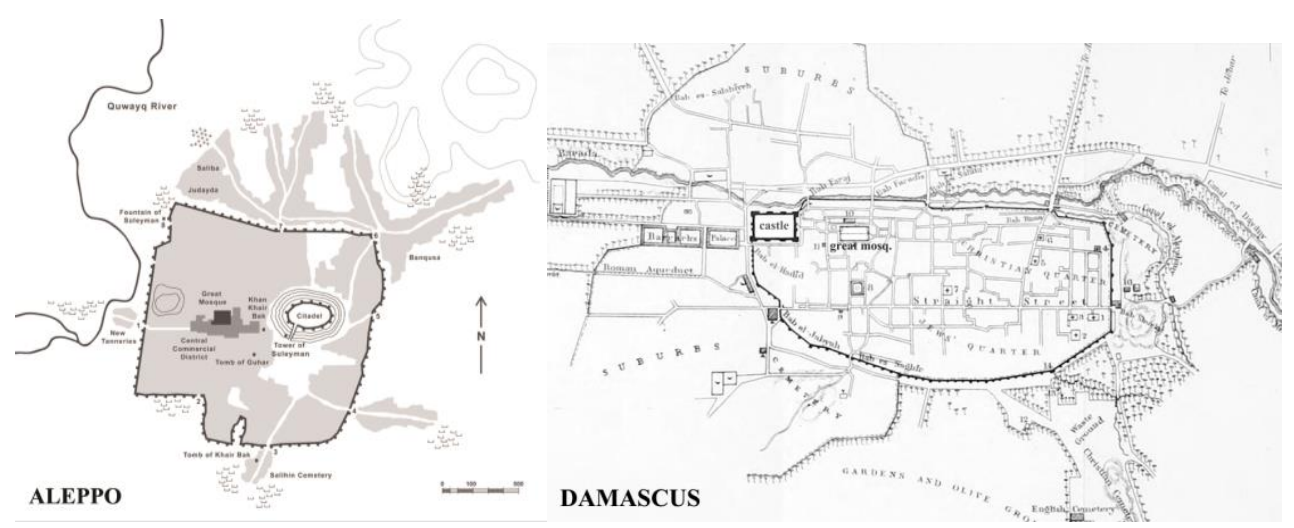

Figure 1. Urban Pattern of Aleppo and Damascus

Source: City map of Aleppo taken from; H. Z. Watenpaugh, The image of an Ottoman city: Imperial architecture and urban experience in Aleppo in the 16th and 17th centuries (Boston: BRILL, 2004.) City map of Damascus taken from; J. L. Porter, Five years in Damascus: Including an account of the history, topography, and antiquities of that city; with travels and researches in Palmyra, Lebanon, and the Hauran (London: John Murray, 1855).

Byzantine city (Figure 2), which was founded with the factors of religious elements and defense elements as its spatial core, ${ }^{15}$ was formed into the districts formed by religious, occupational, and social elements, and has a fortress that was the military-administrative center and economical centers such as bazaars, which defined the city's spatial setup. ${ }^{16}$

There are no adequate archeological studies on the pre-Turkish and post-Turkish urban forms of Medieval Anatolia except a few on structures that have reached our day in some cities. The most general analysis that may be made on the physical texture of the Seljuk era Anatolian cities may be that the palaces were made in citadels that we know from Iran and Central Asia, and there was an internal city (Şehristan) containing a Friday Mosque, a Government Office or a Palace, and an external city containing the markets and towns. ${ }^{17}$ However, the city in the Seljuk Anatolia is not one that Turks established, but one that they discovered. Therefore, as long as there are no natural disasters, it was out of the question that a city with a

15. Considering cities one by one, it may be concluded that Turks acquired two kinds of cities. While there was no clear-cut separation at the time Turks arrived in Anatolia, researchers divided Byzantine cities into two models. One of these is the "multiple-part" city consisting of small, separated residential areas located on the settlement of an ancient city, and the other is the "castle city" with most of the residential areas are located inside fortress walls. U. Tanyeli, "Anadolu-Türk Kentinde Fiziksel Yapının Evrim Süreci (11-15. yy)" ["The Evolutionary Process of the Physical Structure in Anatolian Turkish Cities (11th-15th c.)"] (Ph.D. Thesis in Architecture, İstanbul Teknik University, 1987).

16. K. Özcan, "Erken Dönem Anadolu-Türk Kenti Anadolu Selçuklu Kenti ve Mekânsal Öğeleri" ["Early Anatolian-Turkish Town Anatolian Seljuk Town and its Spatial Elements"],_Bilig [Journal of Social Sciences of the Turkic World] 55(2010): 193-220.

17. O. Turan, "Selçuklu Devri Vakfiyeleri: 1. Şemsettin Altun-aba Vakfiyesi ve Hayatı" ["Seljuk Era Foundation"], Belleten, vol. XI, (1947), 197-235. 
castle and fortress would be destroyed after acquisition and another would be constructed. ${ }^{18}$

The Seljuk administrative system, which was the first Turkish political unity following the Byzantine occupation, provided the Turkish city with an identity composed of a Christian-Byzantine cultural infrastructure by reforming it on the foundation of Middle Asia Turkish and Iran Turkish Islam nomadic or semi-nomadic lifestyle traditions (Figure 2). Seljuks followed a systematic settlement policy for reactivating the international transit trade routes that were deactivated during times of conquest and opened the settlements that were ruined during the dark ages known as the era of conquest and resettlement wars, and fastened the Turk-Islamic colonization of the Anatolian geography that they had taken from under the Byzantine rule. $^{19}$

After the conquest of Anatolia, the first practice that took place in cities taken from Byzantium was converting a church into a mosque as a symbol of conquest. ${ }^{20} \mathrm{New}$ residents of the city also got organized around this structure and settled. ${ }^{21}$ The third part that constitutes the spatial organizing order of the Seljuk city is the market or the bazaar area. In this spatial organization order, social and cultural service organizations are composed of Islamic madrasa-mosque complex composition in function, external walls have been a secondary focus that direct the development of urban development. $^{22}$

18. D. Kuban, Selçuklu Çağında Anadolu Sanatı [The Art of the Seljuk Period in Anatolia] (İstanbul: Yap1 Kredi Publications, 2008), 66-67.

19. For detailed information Ö. L. Barkan, "Osmanlı İmparatorluğu'nda Bir İskân ve Kolonizasyon Metodu Olarak Vakıflar ve Temlikler I" ["Foundaditons and Dispositions as a Method of Colonization in the Ottoman Empire"], Vakıflar Dergisi I(1942): 279-386; Ö. L. Barkan, "Osmanlı İmparatorluğunda Kolonizatör Türk Dervişleri ve Zaviyeler" ["Colonizer Turkish Dervishs and Zawiyas in the Ottoman Empire"], Vakıflar Dergisi, vol. II (1942), 255-353.

20. C. Cahen, Osmanlllardan Önce Anadolu [Anatolia before Ottoman Era], trans. E. Üyepazarc1 (İstanbul: TVYY, 2000), 208.

21. For detailed information on the effects of this practice that may be accepted as a significant conquest tradition in the Seljuk period on the structure of neighborhoods constituting the physical texture of the era; A. Akşit, "Selçuklular Devrinde Kent İskânı ve Mahalleler" ["City Settlement and Districts during Seljuk Empire"], Çankırı Karatekin Üniversitesi Sosyal Bilimler Enstitüsü Dergisi 5, no. 1(2014): 67-88.

22. K. Özcan, Anadolu'da Selçuklu Dönemi Yerleşme Sistemi ve Kent Model(ler)i [Urban Network and Urban Model(s) in Anatolia During the Seljuk Period] (PhD diss., Selçuk University, Konya, 2005) 


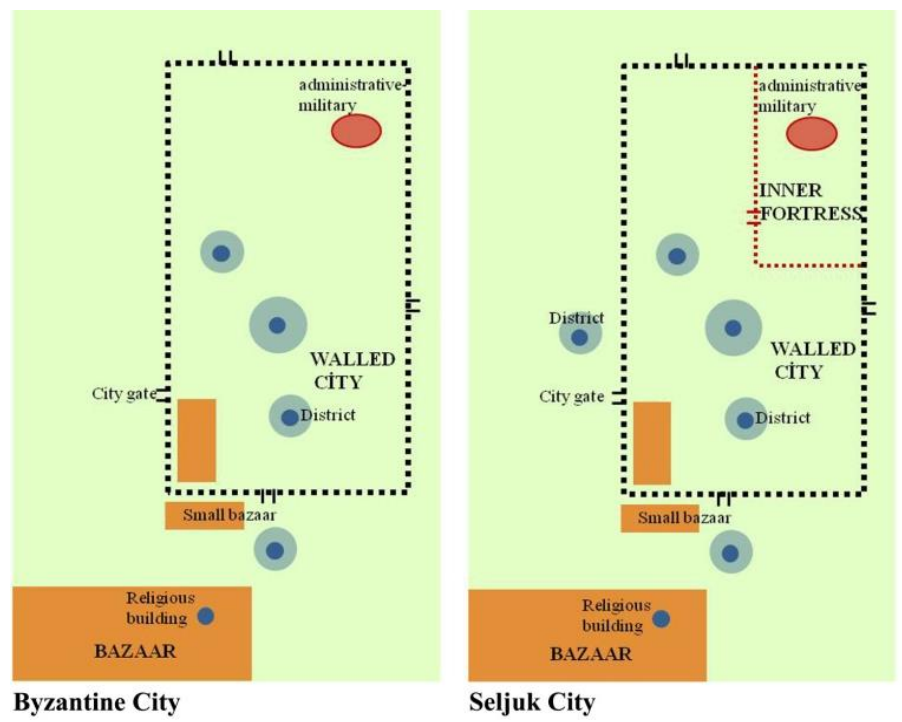

Figure 2. The Illustration of Byzantine and Seljuk City

Source: drawing by Author, 2016

Each urban fabric that ultimately took over the Ottoman city in articulation integrity and its urban tradition ${ }^{23}$ is the continuation of the Seljuk basic colonization elements with military-strategic, economic, religious, social and cultural development within the framework of political and administrative institutions and services ${ }^{24}$ (Figure 3).

Military and Strategical Institutions (Citadel-Inner Citadel); Almost all of the Anatolian cities have citadel which were constructed during the antique era or Byzantine era and defined the boundaries of the city centre. Beside this wall (citadel) cities have an inner citadel enclosed by a later added defense wall which basically functions as the administrative center. Within the perimeter that consisted of the residence of the city governor, the mosque which recently converted from a Byzantine church and answering the religious needs of the new population and strategical institutions as a military structure.

Economical Institutions(Markets and Bazaars, Workshops and Trade Shops); Almost in all of the Western and Islamic cities in the medieval age, bazaars and markets are organized by cantering the religious structures, walls and roads leading to wall gates. ${ }^{25}$

Religious Institutions (Ulu Mosque or Friday Mosque); The main city factor defining the spatial organisation structure off the Turkish cities were

23. The fundamental order the Ottoman urban culture was based on is reflected by the period of carrying out systematic and organized zoning activities regarding transition into settlements such as the restructuring of cities with strategic significance, establishing new cities or rebuilding others, which started in the early Seljuk period settlements, especially by the 13th century. Ibid., 2005.

24. Ibid., 2005, 22.

25. M. Cezar, Tipik Yapılarıla Osmanlı Şehirciliğinde Çarşı ve Klasik Dönem İmar Sistemi [Typical Commercial Buildings of the Ottoman Classical Period and the Ottoman Construction System] (İstanbul: Mimar Sinan University Publication, 1985). 
the mosques which were named Cami-i Kebir (mosque), Sultan Mosque or Great Mosque. $^{26}$

Socio-Cultural Institutions (Islamic Social Complexes); Seljuks constructed service institutions in order to improve the social and cultural city life, provide for the medical services and educational services of the Anatolian cities which were obtained from Byzantine rule. Construction activities mostly conducted by the Sultans, taken the role of developing the city parts outside wall as well as answering to the needs of the populace living within the city walls.

Political-Administrative Institutions (Sultan Palace and Summer-Winter Palace and Manors); Palaces are positioned in the inner castle as the spatial reflection of the state power and authority while the other palaces which were named as summer palaces or palaces outside the city walls were constructed on the near proximity of the cities. ${ }^{27}$

\section{Ottoman City: Change in Urban Pattern/Change Process}

As the extended geography of the Ottoman Empire considered, it is undoubted that the new politics conducted by the new administrative system will result in different changes as the special cultural environment of the cities considered. However, the topic mentioned within this notice will be the applications which were applied to every corner of the empire and adopted as a policy by the Ottomans. As the reflections to the Ottoman Capital and the rural areas differ in terms of scale, they are similar in foundation.

The answer to the question of which factors form the Ottoman City is more complicated than the ones which were formed under the rule of other rulers. ${ }^{28}$ On the long time period that the empire prevailed, on the extended areas expanded to three continents, each Ottoman city developed a format related with their unique dynamics and tradition understandings. If we want to settle the cities in a general frame regardless of the original geographies of the cities, we encounter the time factor. For this reason a typical Ottoman city definition can only be possible by considering the different era topics which have different characteristics and different elements (economical, administrative, technological etc.) in the long time period that the empire ruled.

26. T. Baykara, "Ulucami -Selçuklu şehrinde iskânı belirleyen bir kaynak olarak-" ["Great Mosque-as a source describing the settlement in the city of -Seljuk"] Belleten LX, no. 227(1996): 34-59.

27. S. Redford, "Thirteenth-Century Rum Seljuk Palaces and Palace Imagery," Ars Orientalis 23(1993): 215-232.

28. For detailed reviews of studies conducted on Anatolian-Ottoman cities; M. Öz, "Osmanlı Klasik Döneminde Anadolu Kentleri" ["Anatolian Cities in the Ottoman Classical Age"], TALID 3, no. 6(2005): 57-88. A comprehensive bibliography has been prepared and published by the History Foundation on urban research in Turkey, including historical research. See Kent Araştırmaları Bibliyografyası [Urban Studies Bibliography] (İstanbul: Tarih Vakfi Yurt Publications, 2001). 
The era consisting of the foundation of the empire to the Conquest of Istanbul, defined as the settling period of the Ottoman Culture. ${ }^{29}$ This process carries the specialities of the obtained heritage in terms of the cultural texture as well as seen in the institution and management strategies. Period following this period, especially in the 15th and 16th centuries, though cities carry the traces of the Byzantine, Islam and Seljuk heritages, succeeded to add their unique characteristics to this mix and the Ottoman Empire's unique forms joined the urban pattern. In combination with the acquired heritage, the mosques, imarets, government buildings built by the Ottomans and the markets/bazaars which were the center of economic activities, the Ottoman urban texture came to be, as denoted in the Ottoman fiscal register as "cum'a k1lınur ve bazarı durur". ${ }^{30}$

Rules of the typical Ottoman urban pattern which were described by Cerasi $^{31}$ as wooden houses with broken roofs, a domed mosque, a special order of the city roads, a market the and separation of the economical and residential roles and expansion of the city composition to nature are also the basic factors forming the city structure. The relation of these factors in the Anatolian cities during the Ottoman Empire era with the city parts founded before the Ottoman era, the continuation or demolition of this relation and the tracing of the typological or functional positioning of this relation constitute the main purpose of this study.

\section{City Boundaries}

Ottoman cities were established over the city structure of already present structures, administrative, military, and religious public structures were redesigned to answer to the Ottoman society and management needs, and city centers and nearby areas were opened to new residents. Demographically, according to the change in the identity of the city population by force (conquest-population policies) or automatically increasing the city's population (increasing the number of people or occurrence of different ethnic/religious groups) can be shown in the change in the city's boundaries and the addition of new sections to the city spaces that are not parallel. ${ }^{32}$

Ottoman cities were physically comprised of three sections: the inherited inner fort, a secondary fort that was constituted after the city's expansion that covers the actual city and houses the population and market-

29. M. Akdağ, Türkiye'nin İktisadi ve İçtimai Tarihi 2 [Economical and Social History of Turkey-2] (İstanbul: Cem Publication, 1995).

30. The cities with the Friday mosque and the bazaar were called the city.

31.M. M. Cerasi, Osmanlı Kenti Osmanlı Imparatorluğu'nda 18. ve 19. Yüzyıllarda Kent Uygarlığ ve Mimarisi [Ottoman City Urban Civilization and Architecture in 18th and 19th Centuries in the Ottoman Empire], trans. Asli Ataöv (İstanbul: Yap1 Kredi Publications, 1999), 24.

32. For policies followed in the process of making a city suitable for the Ottoman society and governing needs after an Ottoman conquest; H. İnalc1k, "Ottoman Methods of Conquest," Studia Islamic II (1954): 103-129. 
bazaar, and lastly the suburbs that developed outside the city walls as a result of the demographic change that occurred within the city. The development of the cities evolved around religious, economic, and residential structures for these three-segmented formations. ${ }^{33}$

However, the decline of the walls partially or completely as a result of the disappearance of safety concerns is undoubtedly why the Ottoman Cities were much more developed compared to the almost-prison cities observed in the Byzantine and Seljuk eras.

In this manner, there are two upper topics that can call the Ottoman City structure "settlement modules"34 that directly communicate with the area unrelated to the city walls or related to the city walls via the wall gates. These are the imarets, which are districts where people of the same ethnicity and religion reside together and conduct religious duties together.

Economic and social buildings were articulated on the market, bazaar, and religious structural core, which formed the focal point and center of attractions, and included districts that were organized around religious structures with regard to the texture, and the boundaries of the cities were eventually defined. ${ }^{35}$

\section{Factors of the Urban Patterns: Quarters}

The purpose of worshiping and serving the gods around the world was the main reason for the foundation of the cities, and this provided the development of the "quarter units" that had evolved around religious structures since the antique era (Figure 3).

In the Ottoman era, cities were built of individual quarters. ${ }^{36}$ Ottoman quarters were the smallest administrative units that were capable of managing themselves. Thus, the expansion of Ottoman cities was possible thanks to the creation of new quarters. While quarters that were described as "miniature sections" of the Ottoman social life by Bayramoğlu Alada ${ }^{37}$ had unorganized and complicated physical structures, they were in fact consistent and formatted in terms of the society's needs. ${ }^{38}$

33. Ö. Ergenç, "Osmanlı Şehrinde Esnâf Örgütlerinin Fizik Yapıya Etkileri" [The Effects of the Tradesman Associations on the Physical Structure in Ottoman City], I. Uluslararası Türkiye'nin Sosyal ve Ekonomik Tarihi Kongresi Tebliğleri (1978), 103-109.

34. M. M. Cerasi, Osmanlı Kenti Osmanlı Imparatorluğu'nda 18. ve 19. Yüzyıllarda Kent Uygarlı̆̆ ve Mimarisi, 1999, 70.

35. N. Üstündağ, "Osmanlı'da "Şehir" ve Şehri Geliştiren Unsurlardan Biri Olarak Ayanlar: Vidin ve Rusçuk Örnegi (18.Yüzyıl)" ["The "Ayans" in the Otornan Empire as an Element in the Development of Urbanization and Cities: The Vidin and Rusçuk Example (Eighteenth Century)"], Türkiyat Araştırmaları Dergisi 2(2005): 149-167.

36. K. Alver, "Mahalle: Mekân ve Hayatın Esrarlı Birlikteliği" ["The Neigborhood: The Mysterious Union of Space and Life"] Ideal Kent 2(2010): 116-139.

37. A. Bayramoğlu Alada, Osmanll-Türk Şehrinde Mahalle 9Ph.D. diss., Ankara: Ankara University, 1989).

38. N. Üstündağ, "Osmanlı'da "Şehir" ve Şehri Geliştiren Unsurlardan Biri Olarak Ayanlar: Vidin ve Rusçuk Örnegi (18.Yüzyıl)" ["The "Ayans" in the Otornan Empire as an Element in the Development of Urbanization and Cities: The Vidin and Rusçuk Example 
Cities are developed each day in parallel with their demography, and thus started to expand with the development new quarters related with the new formations conducted by the foundations with increasing population and construction activities (Figure 3). In accordance with the Ottoman city practice that was conducted using their traditional approach following conquest, which is a triggering dynamic of change, suburb formation processes started with the re-allocation of non-Muslims to outside the walls as part of the quarters' foundation or re-foundation processes. A new population and palace were settled inside the walls with official state bureaucrats. The suburbs were settled by people who came afterwards, and they formed a group called "cemaat." These groups developed over time and formed quarters. ${ }^{39}$

The social center in the quarters of the Ottoman city is the mosque. ${ }^{40}$ Required religious buildings were built within the cities on the basis of ethnic and religious groups ${ }^{41}$ requirements, and churches of the remaining or less-observed religions were created if there were non-Muslim districts; this situation was different in the Islamic districts. If the mentioned district occurred through demographic changes in the Christian districts, the needs of worship would be fulfilled through the conversion of already present

(Eighteenth Century)"], Türkiyat Araştırmaları Dergisi no. 2(2005): 149-167. S. Çabuk and K. Demir, Osmanlı Kentlerinde Mahallelerin Mekânsallaştırılabilmesi İçin Bir Yöntem Denemesi: Kayseri Örneği [A Methodological Attempt to Evaluate the Spatialization of Quarters in Ottoman Cities: the Case of Kayseri], Karabük Üniversitesi Tarih Kültür ve Sanat Araştırmaları Dergisi [Journal of History Culture and Art Research] 1, no. 3(2012), 135-153.

39. It is possible to follow the settlement policy after conquest in Trabzon which was conquered in a late period compared to other cities in Anatolia. In the city which was conquered by Fatih the Conqueror in 1461, local people were separated into three groups according to the census which was first done 25 years after the conquest in conformity with new organization Fatih the Conqueror founded. The first group was taken Ottoman Sultans and other servitor pashas' service, the second group was removed from the city to make them settle in other places. The third group was removed from the walled city and was settled to its surroundings. Turkish-Muslim families who came from other cities settled in the walled city. According to this, the Muslim population was recorded in census as 1cemaat (community) and 1 mahalle (district) in 1486. The only district that belonged to Muslims was the district named "Azebân-ı mî-şeved" which was created with people who came to the city voluntarily. For 15-16. century quarters see, H. W. Lowry, The Islamization \& Turkification of the City of Trabzon (1461-1583) (İstanbul: The ISIS Press, 2009); H. Bostan, XV.-XVI. Asırlarda Trabzon Sancă̆ında Sosyal ve İktisadi Hayat [Social and economic life in Trabzon Sancaq in XV-XVI. Century] (Ankara: Publications of the Turkish Historical Society, 2002). For wider evaluation about topic see F. Üstün Demirkaya, Toplumsal Dinamikler Bağlamında Trabzon Kent Dokusunun Dönüşümü (Komnenos Hanedanlı̆̆ı'ndan Cumhuriyet'e Kadar) [Transformation of Urban Fabric in Trabzon in the Contex of Social Dynamics (From Komnenos Dynasty to Republic)] (Ph.D diss., Trabzon: Karadeniz Technical University, 2014).

40. Ö. Ergenç, "Osmanlı Şehrindeki Mahallenin İşlev ve Nitelikleri Üzerine" ["On the Functions and Qualities of the Quarters in the Ottoman City"], Osmanlı Araştırmalarl IV (1984): 69-78.

41. Considering that space was divided into pieces in terms of social classes in structuring of Egyptian, Greek and Roman cities, the history of dividing cities into social and physical sub-units may be taken back to the first emergence of the phenomenon of the cities. 
churches and chapels to mosques, and this was carried out in newly settled places or a district formed by the newcomers through the construction of new religious structures.

\section{Factors of the Urban Pattern: Foundation Complexes-Construction Activities ${ }^{42}$}

The definition of Mumford ${ }^{43}$ "Each generation writes its biography in the buildings it creates" summarizes the roles implied by the city to its residents with its physical structures.

Since the earliest period of the spread of Islamic faith, worship space requirements in conquered areas has generally been met by building mosques, and according to the type of conquest, temples located in seized areas were partially or completely converted into mosques, which provided an example for the later eras to follow. In the tradition of the Ottoman conquest, the conversion of a city's largest places of worship into mosques can be considered as the continuation or reflection of their application in those years. ${ }^{44}$ In summary, cities represent a process of physical change that is formed by the Ottoman "conquest tradition," but that also includes more because of their current statuses. Maybe the tradition of this new culture, which can be considered the most tangible indicator as per construction activities, found meaning in the cities (Figure 3).

The change in this power makes it obvious that the cities enter a process of change that can be described as relative "reconstruction" by describing the new administrative order. Changes in the administrative system might show themselves in architectural formation, construction techniques in methodology, in materials, and even in huge city arrangements in addition to other very limited ways. The Ottoman sultans, especially during the classical era, expressed themselves through the construction of monumental complexes. $^{45}$

42. The item list that belongs to the public for an Ottoman city is long: charities, imaret (the kitchens for the poor), hospital, mental hospitals, teaching constructions: madrasa, primary school, library trade constructions: covered bazaar, inn, caravansary, ottoman bazaar, market, coffee house, management constructions: Palace, mansion, religious constructions: mosque, shrine, lodge and non-Muslims worship constructions, big factories: mint, armoury, shipyard, hygiene constructions: bath, public fountain, fountain, water tank M. M. Cerasi, Osmanlı Kenti Osmanlı Imparatorluğu'nda 18. ve 19. Yüzyıllarda Kent Uygarlı̆̆l ve Mimarisi 1999.

43. L. Mumford, Tarih Boyunca Kent Kökenleri, Geçirdiği Dönüşümler ve Geleceği [The City in History: Its Origins, Its Transformations, and Its Prospects] (İstanbul: Ayrınt1 Publications, 2007).

44. For wider evaluation about the topic see; Ö. İ. Tuluk, Osmanlı Kent Kimliğinin Mistik Öğeleri: Dini Yapılar ve Mezarlıklar [Mystical Elements of Ottoman city İdentity: Religious Buildings and Cemeteries] Hece: Medeniyet, Edebiyat ve Kültür Bağlamında Şehirlerin Dili no.13, (2009): 150-152.

45. C. Can, "Tanzimat ve Mimarlık" ["Tanzimat and Architecture"], in Osmanlı Mimarlı̆̆ının 7 Yüzyılı "Uluslarüstü Bir Miras" (İstanbul: YEM Puplications, 1999), 130-136. 
In the city's heritage from the Seljuks, the mosque continued its role as the focal point of the Ottoman cityscape if the settlement was a city. In cities conquered from the Byzantines, in the process that started with the conquest, the first construction activity was the conversion of the largest church in the city to a mosque, which would represent the new administrative system and signify the city's conquest by building a mihrab and minbar and making it possible to have Friday Prayer and complete its conversion into a mosque. The Ottomans developed a structural and population system to answer social needs, just like the Seljuks.

The urban pattern developed within the new Muslim districts formed in new cities or conquered cities by the construction of mosques or masjids by either foundations or notable persons. However, as a part of the Ottoman population tradition, the presence and sustainability of the structures was important for understanding social and cultural lives. Thus, while mosques and the Muslim society seemed to be in the foreground in Ottoman cities, many non-Muslim elements helped sustain their lives for centuries. ${ }^{46}$

The adoption of the present texture of a city was briefly attempted during the Ottoman era while developing a visual language and a spatial organization that reflected the presence of the new rulers.

\section{Elements of the Urban Pattern; Bazaar-Commercial Areas}

In a typical Ottoman city, the religious and commercial center is a fundamental characteristic. While the religious center develops around the ulu mosque, which can be observed in almost all cities from the early period, Turkish settlements included new structures that were usually covered bazaars and inns, and formed the development focus of the commercial center. ${ }^{47}$

Ottoman bazaars show interesting characteristics due to their urban locations. In the Ottoman urban culture, the strict separation of economic activities and residential areas made the development of a social and economic center necessary. The close proximity of the bazaar to the fort or to the city walls resulted both in them becoming connection points for trade flows and its location and the presence of the roads that allowed the residents to reach the bazaars were the factors that defined the bazaars' urban locations. ${ }^{48}$

46. N. Üstündağ, "Osmanlı'da "Şehir" ve Şehri Geliştiren Unsurlardan Biri Olarak Ayanlar: Vidin ve Rusçuk Örnegi (18.Yüzyıl)", 2005, 149-167.

47. M. M. Cerasi, Osmanlı Kenti Osmanlı Imparatorluğu'nda 18. ve 19. Yüzyıllarda Kent Uygarlı̆̆ ve Mimarisi, 1999, 121.

48. M. S. Şahinalp and V. Günal, Osmanlı Şehircilik Kültüründe Çarşı Sisteminin Lokasyon ve Çarşı İçi Kademelenme Yönünden Mekânsal Analizi [Spatial Analysis of Bazaar Systems: Their Location and Forms in the Ottoman Urbanism Culture], Milli Folklor 24, no.93(2012): 149-168. 
The formation of a bazaar ${ }^{49}$ as the geometrical center of the city expanding around it, can demonstrate that social reinforcement structures formed the required infrastructure tools that helped trade settle down on a solid foundation for the first circle around the covered bazaar and mosque. The structures for the accommodation and clean-up needs of incoming merchants are located within this belt. In this manner, covered bazaars, guest houses, cisterns, ranges, and warehouse structures that were constructed as a requirement of an active economic life both helped the city's economic development and played important roles in the city's physical, architectural, and cultural development.

The second circle of the city "bazaar" is formed by the bazaars of some of the professionals who enable production variety. This ring is generally formed by the workshops that can cause unrest around them, and workshops particularly require water. Bazaars such as tanneries and paint shops that require significant amounts of water during production cycles were established around areas where water was readily available and shops such as tanneries, paint shops, blacksmiths, carpenters, and boiler smiths that can cause bad smells, images, and noise pollution were established in the outer ring. ${ }^{50}$ (Figure 3 )

\section{Elements of the Urban Pattern: Open Spaces and Cemeteries}

Old Turkish cities expressed their identity through their mosques, masjids, madrasas, fountains, hamams, manors, houses, and the cemeteries that surrounded them. ${ }^{51}$ Ottoman cities did not have green in their streets, while each house had trees in the gardens, seemed green from a distance due to the plantation of a tree which is especially a cypress tree on to each deceased person.

In Islamic cities, cemeteries are usually established outside the walls and outside residential areas close to the city gates. Other areas preferred for cemeteries are mountainsides and foothills. In addition, Muslim cemeteries expanded from the small restricted areas established around the foundation of buildings such as mosques or masjids or around the shrines where people wanted to be buried around other deceased people who were important to society. ${ }^{52}$

While those outside the city were resting and tour places, the smaller and monumental ones in the inner part were complete elements of the city

49. M. Cezar, Tipik Yapılarıyla Osmanlı Şehirciliğinde Çarşı ve Klasik Dönem İmar Sistemi [Typical Commercial Buildings of the Ottoman Classical Period and the Ottoman Construction System] (İstanbul: Mimar Sinan University Publication, 1985).

50. M. S. Şahinalp and V. Günal, Osmanlı Şehircilik Kültüründe Çarşı Sisteminin Lokasyon ve Çarşı İçi Kademelenme Yönünden Mekânsal Analizi, 2012, 149-168.

51. S. Eyice, Mezarliklar ve Hazireler, Islam Dünyasinda Mezarlıklar ve Defin Gelenekleri-I [Cemeteries and private graveyards, graveyards in the Islamic world and burial traditions-I] (Ankara: Publications of the Turkish Historical Society, 1996.

52. N. Bozkurt, "Mezarlık" ["Cemetery"], in İslam Ansiklopedisi, vol. 29 (İstanbul: Türk Diyanet Vakfi Publication, 2004), 519-522. 
architecture. Bigger cemeteries were usually located on the exits of the city or districts, and located on the hilltops in a panoramic position, most likely so as to not invade the more fertile valley areas. Cemeteries were rarely surrounded with walls with dense cypress trees that provided a forest view with an arbitrary distribution of tombstones and with mostly observed panoramic positions, used as society gardens, and became places where people toured and were entertained. ${ }^{53}$ These cemeteries, which were located outside the residential areas, conjugated with the city as a result of the expansion of the green areas (Figure 3).

\section{Discussion: The Change Process in Anatolian City}

Cities are not spatial formations that occur for social reasons; instead they have a social formation that is formed spatially. ${ }^{54}$ Continuous social formation causes the seemingly permanent formation of city spaces to repeatedly rearrange or recur. ${ }^{55}$

Changes occurred through economic, technological, political, and legal changes that occurred in all aspects where social life played an important role in the reformation of the Anatolian City space. Especially in the Ottoman Empire, conquest was the first intervention and was the most important dynamic for starting this change process. Changes in the multilayered social and cultural structures of a city were formed through thousands of years of accumulation and can only be described through the construction activities following conquest. Cities taken from Byzantines were converted to Islamic cities by the Seljuks, Beyliks, and finally by the Ottomans. The cities taken from Byzantium were converted into TurkishMuslim cities especially with the zoning activities performed during the Seljuk and Ottoman periods.

However, many unique elements provide distinctions from other Muslim cities in the Ottoman Empire. While forming the Byzantine and Seljuk urban pattern that carried the basic Islamic city characteristics, it also had unique cultural characteristics. Within the extended geography of the Ottoman Empire, which consists of the Balkans, Middle East, and North Africa, Anatolia is a unique city that does not have standard examples in terms of architectural, cultural, or even juridical aspects. It can be seen that the Ottoman city is a synthesis, as it was formed from completely different ethnic, religious, economic, and political structures.

As with the general transformation of the settlement structures; as the spatial reflections of the various military-political conditions of the Ottoman cities, either directly or with Seljuk architecture, can be said to be

53. M. M. Cerasi, Osmanlı Kenti Osmanlı Imparatorluğu'nda 18. ve 19. Yüzyıllarda Kent Uygarlığl ve Mimarisi, 1999, 201.

54. D. Frisby, Cityscapes of Modernity (Cambridge: Polity Press, 2001).

55. E. W. Soja, Postmodern Geographies: The Reassertion of Space in Critical Social Theory 1989); G. Aydoğan Yıldırım, 1980 Sonrası Türkiye'de Kent ve Kentlileşme Kavramlarl [The Concept of City and Civilization in Turkey After 1980] (Master Thesis, Yıldız Technical University, 2006). 
formed by the conversion of Christian institutes into Muslim institutes, just like in the relationship between churches and mosques and the articulation of Islamic complexes and monasteries to Byzantine city spatial structures. However, it can be said that this spatial formation undoubtedly started to change as security concerns declined in both fortified and open cities with nearby forts as a result of the decisiveness regarding topography.

Ottoman conquest was remarkable as a breaking point for the formation of the social and political structure, demography, religion, and physical structure (structures, settlement organization) rather than the changes inflicted on the spatial distribution and functional partitions of the areas in Anatolian cities. The ideological and architectural approaches developed for the city structure were reinforced with the uniting role of the religion factor. New political and religious orders found a demographic and structural representation, and this change expressed itself through the changes in physical texture in Anatolian cities. Particularly the spatial reflections of the changed religious structure may be more clearly followed especially in Byzantine cities that did not contain any Turkish-Islamic elements. It may be argued that the cities taken directly from Byzantium via Ottoman conquest were sometimes formed by transformation of Christian institutions into Muslim institutions as in the case of the church-mosque relationship, and they were formed in other times as additions of Islamic complexes or Turkish-Islamic institutions such as monasteries and hermitages onto the spatial structure of Byzantium.

The reflections of the change in the political and military structure may be seen on fortresses which are one of the most significant physical factors influential on the development of cities since the Middle Ages. While the necessity of protecting the fortresses that played a determining role in the physical appearance and structuring before the Ottomans faded after the conquest, they served another purpose especially in the early times. In cities that harbored the non-Muslim and Muslim populations together, fortresses served as a natural boundary between the settlements of different faiths as the most important indicators of urban settlement.

In this manner, non-Muslims settled outside the city, following the conversion of the city's largest church to a mosque as a requirement of the Ottoman conquest and population policy, volunteers were settled around the very first mosque and the walled city was converted into a Muslim district. The mosque had other social structures, although it was constructed in a non-inhabited area, and the texture was converted and became one of the main elements of the city's plan. These mosques were constructed by the Sultans and can be considered the first construction activities and the redirecting activities for governors, ecclesiastics, etc. Hence, Anatolian cities, especially in the 16th century, reached the image of Turkish-Islamic city states through the structures that were constructed by people and handed over to the associations in the Ottoman order. 


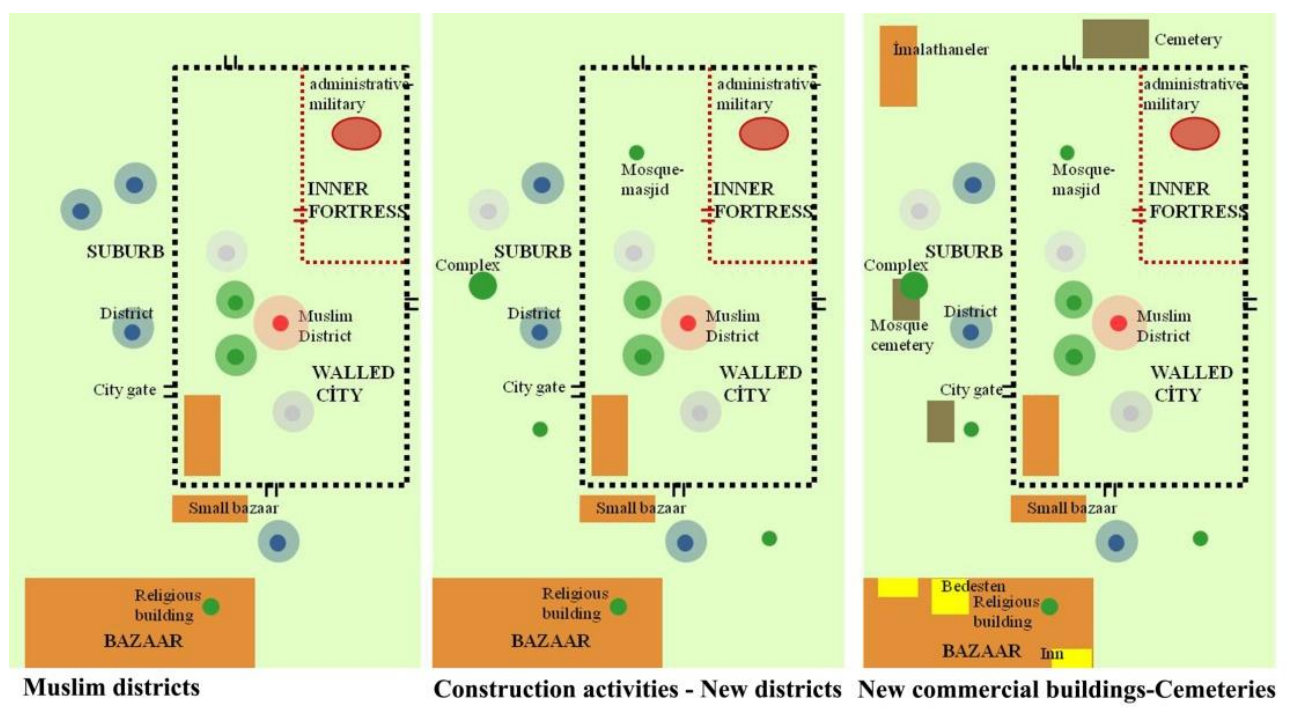

Figure 3. The Illustration of Change process in Anatolian Urban Pattern with New Elements during the Ottoman Period Source: drawing by Author, 2016.

Regarding the cities' Seljuk heritage, it can be understood that the cities developed inside walls around the castles when there were security concerns, while expanding into the suburbs as the population increased and the demographic structure changed, while the commercial areas were physically separated from those defined by the walls by the formation of areas outside the walls that were in relation to the ports and the roads. Shortly, the relationship between the walls and the formation of the physical texture of the Byzantine or Seljuk cities that were stuck within the walls perished and the walls had only the role of demarking the inner castle for governors. Thus, it seems that the relationship between the area defined by the walls and the formation of the city's physical texture weakened, and therefore construction activities conducted in the capital city by sultans and princes in rural areas that supported the spatial expansion occurred in the suburbs of the cities and answered the religious structural needs of the Muslim population. The city center contained many symbols and places.

In the self-dynamics within each era, markets were founded in the urban pattern as per the altered needs while changing the aspects of the settlement area, located within the walls or close to the city gates in relation to the roads and ports. Therefore, commercial zones had an urban pattern that consisted of economic and administrative activities that supported each other. The location of the marketplace reflects the change in public works, although it does not describe the changes in the physical structure during the Ottoman period.

\section{Conclusion}

The findings reached through this study, which focused on reading the reflections of social changes on the physical fabric of the cities through the 
Anatolian-Ottoman city, may be summarized as follows. The first factor that triggers spatial and social changes is "conquest." The second factor is the organization of the society that achieved the conquest, based on their military, political, and economic potential through the spatial infrastructure of the new social order and geography established via the settlement policy used after the conquest. The zoning activities based on this order of organization are determinants of a cities' spatial characteristics.

The Anatolian-Ottoman city was shaped over the spatial structure of the Byzantine and Seljuk cities in this general framework. The urban fabric in the genuine conditions of the Ottoman Empire were divided into four main functional groups: residential, economic activities, religious-cultural activities, and open spaces, while the main principle of the AnatolianOttoman city morphology was based on districts, markets, imarets complexes and cemeteries, and took shape in connection to this functional division.

\section{Bibliography}

Akdağ, M. Türkiye'nin İktisadi ve İçtimai Tarihi 2 [Economical and Social History of Turkey-2]. İstanbul: Cem Publication, 1995.

Akşit, A. "Selçuklular Devrinde Kent İskânı ve Mahalleler" ["City Settlement and Districts during Seljuk Empire"]. Çankır Karatekin Üniversitesi Sosyal Bilimler Enstitüsü Dergisi 5, no. 1, (2014): 67-88.

Aktüre, S. 19. Yüzyll Sonunda Anadolu Kenti Mekansal Yapı Çözümlemesi [Analysis of Spatial Structures at the End of the 19th-century Anatolian Cities]. Ankara: ODTÜ Mimarlık Fakültesi Basım İşliği, 1981.

Alver, K. "Mahalle: Mekân ve Hayatın Esrarl1 Birlikteliği" ["The Neigborhood: The Mysterious Union of Space and Life"]. Ideal Kent 2(2010): 116-139

Aslanoğlu, R. Kent, Kimlik, Küreselleşme [Urban, Identity, Globalization]. Bursa: Asa Publications, 1998.

Aydoğan Yıldırım, G. 1980 Sonrası Türkiye'de Kent ve Kentlileşme Kavramları [The Concept of City and Civilization in Turkey After 1980]. Master Thesis, Yildız Technical University, 2006.

Barkan, Ö. L. "Osmanlı İmparatorluğu'nda Bir İskân ve Kolonizasyon Metodu Olarak Vakıflar ve Temlikler I" ["Foundaditons and Dispositions as a Method of Colonization in the Ottoman Empire"]. Vakıflar Dergisi I(1942): 279-386.

Barkan, Ö. L. "Osmanlı İmparatorluğunda Kolonizatör Türk Dervişleri ve Zaviyeler" ["Colonizer Turkish Dervishs and Zawiyas in the Ottoman Empire"]. Vakıflar Dergisi II(1942): 255-353.

Baykara, T. "Ulucami -Selçuklu şehrinde iskânı belirleyen bir kaynak olarak" ["Great Mosque-as a source describing the settlement in the city of -Seljuk"]. Belleten, LX no. 227(1996): 34-59.

Baykara, T. "Osmanlı Devleti Şehirli Bir Devlet Midir?" ["Is the Ottoman State a Urban State?"]. Osmanl, vol. V, Ankara:Yeni Türkiye Publication, 1999.

Bayramoğlu Alada, A. Osmanll-Türk Şehrinde Mahalle. Ph.D. diss. Ankara: Ankara University, 1989.

Bostan, H. XV.-XVI. Astrlarda Trabzon Sancağında Sosyal ve İktisadi Hayat [Social and economic life in Trabzon Sancaq in XV-XVI. Century]. Ankara: Publications of the Turkish Historical Society, 2002. 
Bozkurt, N. "Mezarlık" ["Cemetery"]. In İslam Ansiklopedisi vol. 29. İstanbul:Türk Diyanet Vakfi Publication, 2004.

Braudel, F. Uygarlıkların Grameri [Grammar of Civilizations]. Translated by M. A. Kılıçbay. Istanbul: Imge Publications, 2006.

Cahen, C. Osmanlılardan Önce Anadolu [Anatolia before Ottoman Era]. Translated by E. Üyepazarc1. İstanbul: TVYY, 2000.

Calvino, I. Invisible Cities. Translated by W. Weaver. Orlando: Harcourt Brace, 1974.

Can, C. "Tanzimat ve Mimarlık" ["Tanzimat and Architecture"]. In Osmanl Mimarlığının 7 Yüzyılı "Uluslarüstü Bir Miras". İstanbul: YEM Puplications, 1999.

Cansever, T. Islamda Şehir ve Mimari [City and Architecture in Islam]. Istanbul: Timaş Publications, 2012.

Cansever, T. Osmanlı Şehri [Ottoman City]. Istanbul: Timaş Publications, 2012.

Cerasi, M. M. Osmanlı Kenti Osmanlı İmparatorluğu'nda 18. ve 19. Yüzylllarda Kent Uygarlığ ve Mimarisi [Ottoman City Urban Civilization and Architecture in 18th and 19th Centuries in The Ottoman Empire]. Translated by A. Ataöv. İstanbul: Yapı Kredi Publications, 1999.

Cezar, M. Tipik Yapılarıyla Osmanlı Şehirciliğinde Çarşı ve Klasik Dönem İmar Sistemi [Typical Commercial Buildings of the Ottoman Classical Period and the Ottoman Construction System]. İstanbul: Mimar Sinan University Publication, 1985.

Çabuk, S., and K. Demir. Osmanlı Kentlerinde Mahallelerin Mekânsallaştırılabilmesi İçin Bir Yöntem Denemesi: Kayseri Örneği [A Methodological Attempt to Evaluate the Spatialization of Quarters in Ottoman Cities: the Case of Kayseri]. Karabük Üniversitesi Tarih Kültür ve Sanat Araştırmaları Dergisi 1, no. 3(2012): 135-153.

Dziewonski, K. "Typological Problems in Urban Geography." Geographia Polonica, 2(1964): 139-144.

Ergenç, Ö., "Osmanlı Şehrinde Esnâf Örgütlerinin Fizik Yapıya Etkileri" ["The Effects of the Tradesman Associations on the Physical Structure in Ottoman City"], I. "Uluslararası Türkiye'nin Sosyal ve Ekonomik Tarihi Kongresi Tebliğleri (1978), 103-109.

Ergenç, Ö. "Osmanlı Şehrindeki Mahallenin İşlev ve Nitelikleri Üzerine" ["On the Functions and Qualities of the Quarters in the Ottoman City"]. Osmanl Araştırmaları IV(1984): 69-78.

Eyice, S. Mezarliklar ve Hazireler, İslam Dünyasında Mezarlıklar ve Defin Gelenekleri-I [Cemeteries and private graveyards, graveyards in the Islamic world and burial traditions- $I$. Ankara: Publications of the Turkish Historical Society, 1996.

Frisby, D. Cityscapes of Modernity. Cambridge: Polity Press, 2001.

İnalcik, H. "Ottoman Methods of Conquest." Studia Islamic II(1954), 103-129.

Kent Araştırmaları Bibliyografyası [Urban Studies Bibliography]. İstanbul: Tarih Vakfi Yurt Publications, 2001.

Kuban, D. Selçuklu Çağında Anadolu Sanatı [The Art of the Seljuk Period in Anatolia]. İstanbul: Yap1 Kredi Publications, 2008.

Lowry, H. W. The Islamization \& Turkification of the City of Trabzon (14611583).İstanbul: The ISIS Press, 2009.

Mumford, L. Tarih Boyunca Kent Kökenleri, Geçirdiği Dönüşümler ve Geleceği [The City in History: Its Origins, Its Transformations, and Its Prospects]. İstanbul: Ayrıntı Publications, 2007.

Öz, M. "Osmanlı Klasik Döneminde Anadolu Kentleri" ["Anatolian Cities in the Ottoman Classical Age"]. TALID 3, no. 6(2005): 57-88. 
Özaslan, N. Konstantinopol'da Bir Osmanlı Kentinin Kuruluşu: Eyüp, [Birth of an Ottoman town in Constantinople: Eyüp], Osmanlı Mimarlığının 7 Yüzyılı "Uluslarüstü Bir Miras". Istanbul: Yapı Endüstri Merkezi Publications, 1999.

Özcan, K. "Erken Dönem Anadolu-Türk Kenti Anadolu Selçuklu Kenti ve Mekânsal Öğeleri" ["Early Anatolian-Turkish Town Anatolian Seljuk Town and its Spatial Elements"]. Bilig [Journal of Social Sciences of the Turkic World] 55(2010): 193-220.

Özcan, K. Anadolu'da Selçuklu Dönemi Yerleşme Sistemi ve Kent Model(ler)I [Urban Network and Urban Model(s) in Anatolia During the Seljuk Period]. $\mathrm{PhD}$ diss., Selçuk University, Konya, 2005.

Porter, J. L. Five years in Damascus: Including an account of the history, topography, and antiquities of that city; with travels and researches in Palmyra, Lebanon, and the Hauran. London: John Murray, 1855. https:// archive.org/details/fiveyearsindamas01 portuoft.

Platon. Devlet [The Republic]. İstanbul: Remzi Publication, 1992.

Redford, S. "Thirteenth-Century Rum Seljuk Palaces and Palace Imagery." Ars Orientalis 23(1993): 215-232.

Rheidt, K. City or Village? Housing and Settlement in Middle and Late Byzantine Anatolia, Tarihten Günümüze Anadolu'da Konut ve Mimarlı [Housing and Settlement in Anatolia A Historical Perspective]. Istanbul: TVY, 1996.

Şahinalp, M. S. and V. Günal. Osmanlı Şehircilik Kültüründe Çarşı Sisteminin Lokasyon ve Çarşı İçi Kademelenme Yönünden Mekânsal Analizi [Spatial Analysis of Bazaar Systems: Their Location and Forms in the Ottoman Urbanism Culture]. Millî Folklor 24, no.93(2012): 149-168.

Soja, E. W. Postmodern Geographies: The Reassertion of Space in Critical Social Theory. New York: Verso, 1989.

Tanyeli, U. "Anadolu-Türk Kentinde Fiziksel Yapının Evrim Süreci (11-15. yy)" ["The Evolutionary Process of the Physical Structure in Anatolian Turkish Cities (11th-15th c.)"]. PhD diss. in Architecture, İstanbul Teknik University, 1987.

Tekeli, I. Anadolu'da Yerleşme Sistemi ve Yerleşme Tarihleri [Anatolian Settlement System and Settlement Dates]. Istanbul: TVYY, 2011.

Tuluk, Ö. İ. Osmanlı Kent Kimliğinin Mistik Öğeleri: Dini Yapılar ve Mezarlıklar [Mystical Elements of Ottoman city İdentity: Religious Buildings and Cemeteries]. Hece: Medeniyet, Edebiyat ve Kültür Bağlamında Şehirlerin Dili no. 13(2009): 150-152.

Turan, O. "Selçuklu Devri Vakfiyeleri: 1. Şemsettin Altun-aba Vakfiyesi ve Hayatı" ["Seljuk Era Foundation"]. Belleten XI(1947): 197-235.

Üstün Demirkaya, F. Toplumsal Dinamikler Bağlamında Trabzon Kent Dokusunun Dönüşümü (Komnenos Hanedanlığı'ndan Cumhuriyet'e Kadar) [Transformation of Urban Fabric in Trabzon in The Contex of Social Dynamics (From Komnenos Dynasty to Republic)]. Ph.D diss., Karadeniz Technical University, 2014.

Üstündağ, N. "Osmanlı'da "Şehir" ve Şehri Geliştiren Unsurlardan Biri Olarak Ayanlar: Vidin ve Rusçuk Örnegi (18.Yüzyıl)" ["The "Ayans" in the Otornan Empire as an Element in the Development of Urbanization and Cities: The Vidin and Rusçuk Example (Eighteenth Century)"]. Türkiyat Araştırmaları Dergisi 2(2005): 149-167.

Watenpaugh, H. Z. The image of an Ottoman city: Imperial architecture and urban experience in Aleppo in the 16th and 17th centuries. Boston: BRILL, 2004. 